\title{
Ethical Leadership and Deviant Workplace Behaviour: The Role Ethical Reasoning, LMX, Distributive Justice, and Psychological Safety and Attachment in a Moderated Mediation Framework
}

\author{
Anum Naz \\ Research Scholar \\ Karachi University Business School, University of Karachi, Pakistan \\ E-mail: annumtaj@gmail.com \\ Dr. Danish Ahmed Siddiqui \\ Associate Professor \\ Karachi University Business School, University of Karachi, Pakistan \\ E-mail: daanish79@hotmail.com,danishsiddiqui@uok.edu.pk
}

Received: October 6, $2021 \quad$ Accepted: November 5, 2021 Published: November 10, 2021

doi:10.5296/gjes.v7i2.19170 URL: https://doi.org/10.5296/gjes.v7i2.19170

\begin{abstract}
The article aims to analyse and explain the relationship between ethical leadership, organisational deviance. We proposed a theoretical framework arguing a mediatory role of situational factors including psychological safety, psychological attachment, distributive justice, and Leader-Member Exchange (LMX). We also argue that utilitarian based ethical reasoning make employees more responsive towards the ethical decision by the leadership making them less deviant. Empirical validity was established by conducting a survey using a close-ended questionnaire. Data was collected from 254employees and analysed using confirmatory factor analysis and structured equation modelling. The measurement and structure model were assessed using AVE (average variance extracted), Composite Reliability (CR), Cronbach's alpha, discriminant validity through the Fornell-Larcker Criterion, and Collinearity methods in PLS-SEM. The results suggested a significant and positive effect of ethical leadership on Leader-member-exchange, psychological attachment, distributive justice, and psychological safety. Moreover, apart from distributive justice, all other factors seem to
\end{abstract}




\section{Macrothink}

Global Journal of Educational Studies

ISSN 2377-3936 2021, Vol. 7, No. 2

decrease Organisational Deviance, however, their effect remained insignificant. Surprisingly, ethical leadership (EL) seems to be directly instigating Organisational Deviance (OD), as well as through the mediation of distributive justice. However, EL seems to significantly reduce deviance through including Utilitarianism ethical reasoning amongst its followers, as EL seems to positively affect utilitarianism, which in turn negatively affects deviance. Utilitarianism also seems to complement EL in reducing OD directly as the result showed significant and negative complementarities amongst EL and Utilitarianism in explaining OD. The results imply that EL and OD nexus is more affected by ethical reasoning rather than situational factors.

Keywords: Ethical Leadership, Leader-Member Exchange (LMX), Distributive Justice, Utilitarianism, Psychological safety, Psychological Attachment, Organisational Deviance, Employee Behaviour 


\section{Introduction}

\subsection{Background of the Study}

Today, the issue of ethics in organisations is an interesting topic to be discussed especially for the issue of unethical or deviant behaviour. Therefore, this issue becomes a major concern in an organisation and business field. Unethical or deviant behaviour will produce a negative implication on individuals, groups, and organisation in which it encourages practitioners and academicians to give more attention to the ethical management. Deviant behaviour has a negative influence on an organisation as stated by some researchers; unethical behaviour seems to have a further impact on the evasion of customers. Frederiks et al. (2016) explained that unethical behaviour will increase the financial risks and costs as well as decrease the value of the company which in turn will lower the return to the stakeholders. On the other hand, Henle (2005) in his research believed that unethical or deviant behaviour has influenced the decrease of productivity and performance in an organisation.

In the long-term period, negative implications caused by this behaviour will affect the competitive strength of the organisation. This also affected the performance of the individual significantly and negatively. Moreover, there is a surcharge that came up because of the negative effect on performance and productivity. Low quality of work, lost working time, high legal and health costs as well as the negative effect on public perception. The researchers have a different term of deviant behaviour such as workplace deviance, counterproductive behaviour, antisocial behaviour, misbehaviour and organisational misbehaviour. Counterproductive work behaviour and antisocial behaviour are a different terminology which is also used for unethical work behaviour.

However, the point is that these activities have a common sense which is a significant violation of organisations or social norms. Thus, it has negative implications for the organisation and its members. Deviant behaviour is caused by many things as it is in accordance with the research of Erkutlu and Chafra (2019). He showed that there is an extensive ground in deviant behaviour which includes negative working cognition, acceptable injustice, anger, hostility and revenge. In addition to that, Erkutlu and Chafra (2015) revealed that deviant behaviour in the workplace is caused by resign intention (intent to quit), dissatisfaction and lack of appreciation. Christian and Ellis (2014) also confirmed that the factors responsible for deviant behaviour consist of financial pressure, low job satisfaction, inequality, working environment issue and workers' perception. Whilst according to Frederiks et al. (2016), there are four main factors which could cause deviant behaviour, namely, organisational issue, behavioural model, operational environment, and individual perspective.

Ethnical leadership is important in multiple ways which allow a person to do right thing on a right time in a proper manner, respect, honour, honesty, leadership, and values awareness not just with locals, employees, customers and a whole company. Ethnical leadership works on the above ethical concept and here the utilitarianism is linked with this theory in multiple ways. As the ethnical leadership explains the "leadership representative and endorsing normatively to conduct through individual movements and relational relations". Utilitarianism grips that ethical action in right if it have a tendency to to indorse happiness and if it tends to indorse 
sadness, wrong impact or the reverse of happiness not just the happiness of the person but other would also be affected by it.

Researchers like Christian and Ellis (2014) have used the social cognitive theory to underline the occurrence of organisational deviance. In line with the social cognitive theory, organisations that lack ethical leadership often produce morally disengaged employees who tend to move away from self-regulation. Besides, the psychological contract theory has been utilised by some researchers to firmly understand the behaviour of employees concerning the attitudes of their leaders and/or employers.

\subsection{Problem Statement}

In any organisation of Pakistani, the level of organisational deviation can include the use of profanity or physical violence and attempts to humiliate a colleague. Whilst most Pakistani organisations seek to create a healthy work environment that boosts teamwork and maximises efficiency, there are situations where employers or employees intentionally display deviant behaviour. This negatively affects the entire organisation and makes it difficult for the company to achieve its goals. Whilst the phenomenon of deviant behaviour in the workplace is not new, globalisation, flexible technology environments, increased competition, workplace stress and materialism have actually increased the impact of deviant behaviour in the workplace. This, in turn, affects employee morale and their pursuit of success. Hence, it is important to inspect and fix the problem.

For some time, management scholars have argued that pioneers of an organisation gain advantages in their organisations by monitoring cash flows and imposing moral standards in the work environment. In any case, at a time when quick financial returns are required, there are a striking number of striking examples of the "benefit at any cost" mind set, where moral driving is a supportive concern for productive work. Instead, Gerpott et al., 2019) recommended this moral initiative, described as "demonstrating normatively informed leadership through close to home action and family ties, and promoting this direct approach to adherents through two-way correspondence, support, and decision making. Gils et al. (2014) is a respectability-based conditional way of working with management that promotes moral responsibility, but also encourages representatives to engage in practices that contribute to long-term organisational achievement.

Organisational deviance has been defined as voluntary actions at work that violates the norms of the organisations acting as a threat to the well-being of the organisations as well as the members (Erkutlu \& Chafra, 2019). The banking sector of Pakistan has emerged as one of the most important for the economy of the country. According to Butt et al. (2016) consistent performance within the sector is attributed to the efforts of ethical leaders. Different policies have been put forward by the government of Pakistan to improve deviant behaviour within the public and private banking sector, but the problems continue to exist. Gill et al. (2016) noted that any gaps in ethical leadership ultimately lead to deviant behaviour. To add on, experience from the research of Dar (2017) has shown that most organisations run by the government in Pakistan, whether autonomous or semi-autonomous are mostly challenged due to deviant employee behaviour. 


\subsection{Gap Analysis}

Several studies have examined the relationship between ethical leadership and diverse forms of unethical behaviour comprising the organisational employee, employee misconduct and bullying. The results of this study also indicate that when the leader's behaviour is normative and in accordance with the business ethics, workers will be happier to get engaged and less likely to behave unethically and counterproductively. In the past decade, some researchers that discussed the relationship between ethical leadership and deviant behaviour have revealed diverse results. Some researchers claimed that ethical leadership is able to affect deviant behaviour directly and significantly.

Erkutlu and Chafra (2019), found that there is no significant relationship between ethical leadership with counterproductive behaviour, Gils et al. (2014) also believed that ethical leadership had no significant effect on interpersonal and organisational deviant behaviour. Based on some previous research, the relationship between leadership and employee behaviour has not shown any solid evidence that unethical and ethical behaviour is generated as a result of an ethical leadership pattern. Several empirical studies which discuss the effect of ethical leadership against deviant behaviour has revealed that there are in consistencies within the study so that the research gap is interesting to be revealed.

Thus, as an innovation in this study, we incorporate the situational factors including psychological safety, psychological attachment, distributive justice, and Leader-Member Exchange (LMX) as a mediating variable in the relationship between ethical leadership and deviant behaviour. in the workplace as well as exploring the mediation and moderation effect of utilitarianism based ethical reasoning between EL and OD nexus. We argue that utilitarian based ethical reasoning make employees more responsive towards the ethical decision by the leadership making them less deviant. Moreover, EL also inculcate utilitarianism amongst the followers again making them less deviant Gill et al. (2016). This is a novel attempt as no previous study attempted to give a framework on how situational factors along with ethical reasoning affect EL-OD nexus. Hence, we combined two different strands of literature into a unified structural framework. Moreover, no previous study offered to explain this n Pakistani context. Hence, this would further extend the research frontier and provided a much-needed generalisation of Ethical Leadership literature.

\subsection{Research Objectives}

This article aims to determine the relationship of ethical leadership and organisational deviance as well as how factors such as psychological safety, psychological attachment, distributive justice, Leader-Member Exchange (LMX) and Utilitarianism play a mediating role in impacting organisational deviance. We proposed a theoretical framework arguing a mediatory role of situational factors including psychological safety, psychological attachment, distributive justice, and Leader-Member Exchange (LMX). We also argue that utilitarian based ethical reasoning make employees more responsive towards the ethical decision by the leadership making them less deviant.

R01: To analyse and understand the relationship between ethical leadership and organisational 
deviance

RO2: To examine the impact of psychological safety, psychological attachment, distributive justice, Leader-Member Exchange (LMX) and Utilitarianism on organisation deviance

RO3: To identify the connection between psychological safety, psychological attachment, distributive justice, Leader-Member Exchange (LMX) and Utilitarianism and ethical leadership

RO4: To analyse and estimate the effect of utilitarianism in a moderate manner.

\subsection{Significance of the Study}

This article will create benefits for the government and the banking sector of Pakistan to make policy changes that will stimulate a reduction in organisational deviance. The banking sector of Pakistan can use this article to create training programs based on the mentioned factors to increase the efficiency of the sector and thus make it more effective and profitable. With a detailed look on the factors influencing organisational deviance, this article can be of vital significance to managers of banks helping them understand the shortcomings of their organisations and strategies accordingly to reduce deviant behaviour at the workplace.

\subsubsection{Organisational Deviance}

The concept of deviant behaviour was expressed by Gerpott et al. (2019) who argued that deviant behaviour arose because of a lack of motivation to conform to organisational rules so as to be motivated to violate the rule. The concept was then developed by Friedland et al. (2020) in his research on deviant behaviour which focused on the "right" or "wrong" behaviour established in the form of justice, law or other social guidelines that determine morality. Then, Friedland et al. (2020) added the argument of deviant behaviour in the workplace with a more comprehensive concept that the behaviour which violates the norms and interferes the survival of the organisation is shared on the multi-dimensional scale of both interpersonal and organisational. The relationship between leadership and employee behaviour refers to the opinion of Forthmann et al. (2019) that leader is certainly affecting its subordinates.

The appropriate theory to underline the influence of ethical leadership and deviant behaviour in the workplace is Social Learning Theory expressed by Erkutlu and Chafra (2015), he explains the influence of ethical leadership toward the subordinates to learn the appropriate behaviour through the process of role modelling by observing the behaviour of others. In this case, leader acts as a role model that is credible and, at the same time, is attractive because of its authority to punish and reward. In addition to Social Learning Theory, the relationship between ethical leadership with deviant behaviour can be explained by the Social Exchange Theory from Christian and Ellis (2014) which describes that social exchange is based on both transactional (economic exchange) or socio emotional(interpersonal behaviour exchange). These two foundations are essential to understand the process of social exchange that is relevant to ethical leadership. 


\subsubsection{Ethical Leadership and Deviant Behaviour in the Workplace}

There has been a prolonged concern for scholars regarding the relationship between organisational deviance and ethical leadership. Christian and Ellis (2014) suggest that low ethical leadership experience may lead to frustration of employees resulting in direct unethical behaviour. Organisational deviance, as defined by Christian and Ellis (2014) refers to voluntary behaviour at work that violates norms of the organisation threatening the reputation of not only the organisation but also its members. Leaders with ethical values strive to create an ethical climate based on trust (Decoster et al., 2019).

Furthermore, when employees perceive equal and fair treatment within the organisation, they engage in building trust with their leaders and are less likely to engage in deviant behaviour. Resultantly, the following hypothesis can be proposed. Ethical leadership is effective in preventing deviant behaviour, whereas at the same time the leader is able to create a good organisational life. According to Social Learning Theory, explaining the effect of ethical leadership to subordinates by learning the appropriate behaviour through role modelling process as well as by observing others 'behaviour in this case is the leader who acts as a role model that is credible and attractive, whereas at the same time it has the authority to punish or to rewards.

In addition to that, the relation between ethical leadership with deviant behaviour can be explained by Social Exchange Theory from Blau (1964) which describes the social exchange that is based on two aspects such as transactional (based on economic exchange) and socio emotional (based on interpersonal behaviour exchange) Dust et al. (2018). Both of these aspects are important to be understood if we want to know the relevant process of social exchange to ethical leadership. Several studies have significantly examined the relationship between ethical leadership with various forms of unethical behaviour, including deviant behaviour, employee misconduct and bullying. Those studies also revealed that the increased ethical leadership will reduce employee's deviant behaviour in the workplace, whereby when leaders behave ethically and normatively in line with ethical behaviour, the workers will also pleasantly involve in work and less likely to engage deviant behaviour. Based on the results above, the hypothesis of this study is proposed as Follows:

\section{H1e: Ethical leadership and organisational deviance have a negative significant relationship}

\subsection{Ethical Leadership}

$\mathrm{Xu}$ et al. (2016) regard managers or supervisors as core agents of any organisation. The actions of managers or supervisors are often translated by their employees or subordinates as providing information about commitment and intentions of organisations (Shareef \& Atan, 2019). However, Dust et al. (2018) have argued that there is a possibility of an imbalance between the personal interests of a manager and that of the organisation. There is a need for further research to explicate the alignment of personal and organisational interests within an organisation (Rani \& Samuel, 2016). Aryati et al. (2018) believed that organisations need ethical leadership for the creation of an ethical climate. Concerning the social learning theory of Bandura (1986), 
cited by Qing et al., (2019) noted that an ethical climate promotes ethical practices that further drive the continuation of ethical leadership. Ethical Leadership, as defined by Xu et al. (2016), is the use of personal actions by managers to demonstrate apposite conduct. This conduct is further elevated to subordinates through two-way communication, reinforcement, and decision-making.

\subsubsection{Leader-Member Exchange (LMX) and Ethical Leadership}

Graen and Uhl-Bien (1995) proposed the Leader-Member exchange theory (LMX) to focus on the relationship between leaders and members within an organisation. According to Yuan et al. (2018), the LMX theory constitutes of various relationships of exchange that leaders tend to develop with their followers. Arguably, Breevaart and Zacher (2019) suggested that from the perspective of the follower, the leader is assessed based on trust. According to PircherVerdofer and Peus (2020), the leader and member have an ethical value congruence which relates to the agreement degree between the value system of the leader and that of the member. Hu et al. (2018) suggested that a high degree of agreement results in a high LMX. It has been suggested by evidence from the study of Abdillah et al. (2020) that altruism, empowerment and ethics in leadership promote high-quality LMX relations. About Blau's (1964) theory of social exchange, Cropanzano et al. (2017) found that employees develop relationships of high-quality with the people that they interact with. Based on the literature findings, it is hypothesized that:

\section{H1a: Ethical Leadership behaviour has a positive influence on LMX}

\subsubsection{Psychological Safety and Ethical Leadership}

Psychological safety, as described by Hu et al., (2018) is beyond the perceptions of high levels of interpersonal trust. Concerning the study of Newman et al., (2017), psychological safety arises due to mutual respect between leaders and subordinates within the work climate. Employee psychological safety can be affected by both organisational and personal factors. Employees that are entrusted by leaders and are given the full freedom to express their opinions tend to ease out from the pressure of interpersonal risks (Weiss et al., 2018). The social information processing theory of Joseph Walther (1992) guides that the behaviours of people are driven by their social environment (Pang et al., 2018). Regarding literature, the following hypothesis can be generated:

\section{H1b: Ethical Leadership has a positive relationship with psychological safety.}

\subsubsection{Psychological Attachment and Ethical Leadership}

The study of Sreeprabha (2018) highlighted that engagement of leaders with moral management enables leaders to reinforce balanced and value-driven approaches to business. For instance, Hu et al. (2018) noted that ethical leaders provide a calm and safe atmosphere to their subordinates thus making it easier for members to work in an ethical climate. Additionally, Dust et al. (2018) noted that followers working under moral leaders are highly motivated to work toward success creating an attachment to work as well as the interests of the organisations. The work of Lysova et al. (2019) suggested that ethical leadership behaviour motivates employees to identify with the organisation. It can further be hypothesized that: 


\section{Al Macrothink}

Global Journal of Educational Studies

ISSN 2377-3936

2021, Vol. 7, No. 2

H1c: There is a positive relationship between ethical leadership and psychological attachment

\subsubsection{Distributive Justice and Ethical Leadership}

$\mathrm{Xu}$ et al. (2016) described distributive justice in relation to fairness and equality. Employees compare outcomes received individually to those of their colleagues. Al Halbusi et al. (2017) argued that distributive justice is something beyond the perception of equal pay and promotion opportunities. It also entails equality in decision outcomes as well as resource allocation (Alpkanet al., 2020). Many past empirical studies have demonstrated a relationship between organisational justice and ethical leadership. There is greater trust in the organisation when employees are exposed to an ethical climate (Xu et al., 2016). Fair treatment by leaders results in employees perceiving their behaviour positively. As assumed by Mohammad et al. (2019), distributive justice contributes highly to improved employee psychological condition. Thus, the following hypothesis can be drawn:

\section{H1d: Ethical Leadership and distributive justice are positively related to each other}

\subsubsection{Leader-Member Exchange and Organisational Deviance}

Weak relationships between leaders and members can lead to low-quality LMX relationships thus increasing deviant workplace behaviour (Valle et al., 2019). Employees blamed for poor actions of their supervisors have increased feelings of injustice and dissatisfaction. Minimum or no interactions between leaders and their followers often results in communication gaps (Al Hakim \& Soetjipto, 2020). Weak LMX relationships lead to employees tarnishing the image of their supervisors as they tend to talk ill about them with their colleagues. The study of Hu et al. (2018) suggested that when LMX relationships are of high quality, employees have a strong voice behaviour, in that they can freely express discomfort to the leaders thus avoiding organisational deviance. This leads to the proposition of the following hypothesis:

\section{H2a: LMX is negatively related to organisational deviance}

\subsubsection{Psychological Safety and Organisational Deviance}

Liu et al. (2016) perceived psychological safety as perceptions held by individuals of the consequences following the engagement in interpersonal risks in the organisational environment. Research conducted by Erkutlu and Chafra (2015) demonstrates that psychological safety feelings are contributed by certain leader characteristics. Research further noted that when in a benign environment, individuals are ready to seek assistance, tolerate mistakes and encourage others toward efficient and effective ways of working for organisational goals (Erkutlu \& Chafra, 2019). Moreover, leader openness, availability and convenience facilitate comfort for employees thus introducing psychological safety at work (Erkutlu \&Chafra, 2015). Low psychological safety implies that employees will demonstrate low identification toward the leader and the organisation (Chughtai, 2016). It can further be hypothesized that:

H2b: Psychological safety and organisational deviance are negatively related to each other. 


\subsubsection{Psychological Attachment and Organisational Deviance}

Luke et al. (2020) explained psychological attachment as a deep enduring bond between two entities in the presence of an attachment figure. According to Erkutlu and Chafra (2019), psychological attachment mediates the reduction in organisational deviance through good and fair leadership practices. Unfair leadership practices such as unequal appreciation, rewards and opportunities may lead to frustration amongst employees (Luke et al., 2020). Similarly, Hackett et al. (2018) argued that leaders that show concern and support to their subordinates create a mutual trust relationship with the subordinates. In turn, this motivates employees to identify the organisation as their, creating psychological attachment. Following the literature, it can be hypothesized that:

\section{H2c: There is a negative significant relationship between psychological attachment and organisational deviance}

\subsubsection{Distributive Justice and Organisational Deviance}

Relating to the equity theory proposed by John Stacey Adams in 1963, employees draw a comparison between their perceived rewards and contributions and efforts to those of their colleagues. Dar (2017) stated that if individuals perceive any kind of injustice in the distribution of rewards and resources, frustration and resentment take over their minds leading to behavioural reactions. It has been revealed by various studies that distributive justice results in job satisfaction and commitment to the organisation. Jehanzeb and Mohanty (2019) drew a relationship between distributive justice and organisational deviance. The study argued that employees are likely to be affected by unfair practices in organisation decisions and actions. With the study of Dar (2017), the following hypothesis can be proposed:

\section{H2e: Distributive justice is negatively related to organisational deviance}

\subsection{Ethical Leadership - Utilitarianism and Organisational Deviance}

\subsubsection{Utilitarianism and Organisational Deviance}

Utilitarianism has been considered as one of the most widely understood and applied ethical theory (Lindebaum et al., 2017). Referring to the organisational context, van Berkel et al. (2020) said that utilitarianism states that a decision concerning a business is only deemed morally right or wrong depending on the effects of that decision. Friedland et al. (2020) argued that utilitarianism suggests that every individual is responsible for the happiness of others in the workplace environment. Monrouxe and Rees (2017) identified honesty, professionalism, accountability and avoiding conflicts of interests as some of the core values of a utilitarian workplace. This leads to the hypothesis that:

\section{H2d: Utilitarianism is negatively related to organisational deviance}

The study of Gils et al. (2014) suggested that utilitarianism and ethical leadership have been proven successful for many organisations in recent years. Employees that are shown care and support deliver work with motivation and commitment (Gill et al., 2016). Moreover, Gerpott et al. (2019) stated in their study that ethical leaders use their principles to transform the morally 
wrong actions into the right ones even if they produce good outcomes for the organisation. Such determination from the side of the leaders influences employees to give their best and involve in the good actions of the organisation to create for themselves a healthy and positive reputation. Based on literature, it is further hypothesized:

\section{H3: Ethical leadership has a significant and positive effect on utilitarianism}

It is important to note that besides the great degree of divergence that exists between the moral instincts of various classes and individuals, there is often a palpable disagreement between the moral instincts of a class or an individual and utilitarian reasoning such as their untrained intelligences are used to leading. There are many things in conduct that many people believe to be right but improper, or at least that they would not have thought fit if they had not first judged them to be right; in so far as they reason by experience alone, their conclusions concerning what leads to general happiness are opposed to their moral intuitions.

Knights and O'Leary claim that ethical leadership is "ethical" in that it involves adherence to a certain school of ethical thought: (a) philosophical selfishness; (b) utilitarianism; (c) Kantianism; (d) the theory of justice; (e) the ethics of responsibility.

Bowie relativises the moral behaviour of the transactional leader, he seems to idealise that of the transformational leader. According to him, the transformational leader clearly manifests a professional ethics. Kanungo identifies as "utilitarian altruism" the combination of altruistic concern and concern for the self-interest sought by the individual, so that the leader's behaviour leads to consequences which are mutually beneficial.

Kanungo defines two approaches to judge the ethical character of a behaviour: (A) teleological ethics (centred on the ends sought, the results): this is a consequentialist vision. The morality of a behaviour then depends on the net consequences of the action, whether it is a utilitarian view of things (happiness equals pleasure less suffering; maximising the happiness of the greatest number of people affected by the decision) or hedonistic (anything that gives pleasure is good).

Either style of leadership can adhere to Kantianism or utilitarianism. The school of philosophical thought to which a leader adheres is not inseparable from his style of leadership.

Moreover, by insisting too much on the school of philosophical thought more or less consciously chosen by the leader, one obliterates, suddenly, the often-decisive influence that religious-spiritual beliefs and values can have on the choice of style of leadership Cropanzano et al. (2017). In short, ethical leadership is not "ethical" simply because it reflects the leader's adherence to one of the schools of philosophical thought (philosophical egoism, utilitarianism, Kantianism, ethics of virtues, theory of justice, etc. ethics of responsibility). There is also no gradation between these schools of thought. The real test of the ethical character of leadership consists in its treatment of the rights, needs and interests of both communities and individuals.

H4: Utilitarianism significantly moderate the effect of ethical leadership on organisational deviance in a way that the positive (negative) effect of ethical leadership is strengthen (weaken) by utilitarianism based ethical predisposition of the followers. 


\section{Macrothink}

\section{Methodology}

\subsection{Research Design}

This study is confirmatory research. Forthmann et al. (2019) define confirmatory research as one that checks the credibility of the formulated hypothesis. This is further an indication that previous research on the subject has been conducted and findings have been published. Furthermore, this is a quantitative study in which statistical data, standardised in nature is used to conclude.

\subsection{Research Approach}

Tuffour (2017) defined two types of research approaches - inductive and deductive. This study uses the deductive approach in which quantitative data is retrieved from participants in the form of statistical data.

\subsubsection{Primary Data Collection Methods}

The first-hand approach to results of an author is known as primary research which involves surveys, interviews and experiments (Frederiks et al., 2016). The researcher used google forms to reach out to participants for filling the survey questionnaire.

\subsection{Sampling}

The current study planned to use targeted experiences to sort information. The rationale for using targeted testing was that it allowed the analyst to gather information with the help of specific professionals, targeting a population or area. This also led to direct transmission to members and the receipt of the necessary information and results related to the purpose of the study. This study included a 254-sample size which is good enough to investigate the relationship between organisational deviance and ethical leadership. The sample size consists of bank employees from banks such as Habib, Faysal, Meezan, Soneri, Sindh and Bank Al Habib.

\subsection{Instrument}

The main sources of data collection for the analysis of research questions are primary and secondary. Surveys are primary sources and secondary sources are journal articles, and books etc.

\subsection{Structural Equation Modelling}

We used a SEM to test the research theory, and testing was done using Smart PLS programming. In addition, testing has been completed to assess the divergent and direct impacts of a relative set of developments. The use of the primary state model (SEM) was considered the first system to be used in various relapse models and methods Cropanzano et al. (2017). It is used to assess the underlying relationship between exogenous and endogenous factors. It includes factor expertise and multivariate research. In addition, the relapse condition focuses on uncovering each development in order to explore the circumstances and relationships of logical outcomes, whilst the set of components in a causal model can show 
their circumstances and logical outcomes at a specific time. Moreover, using this model ensures that a bootstrap method is applied that is considered reasonable for both small and huge examples and does not require any workaround Chughtai, (2016). To check for all forward and workarounds, a procedure known as bootstrapping was performed.

\subsection{Measurement of Outer Model}

The purpose of the conformity relationship in the valuation model is to learn about the reliability and legitimacy of the instrument, and to test its unshakable quality and legitimacy. We test the simultaneous legitimacy and discriminant legitimacy of the Smart PLS name programming.

\subsection{Factor Loadings Significant}

The table of illustrative measurements also indicates the loads used in the confirmatory factor study (CFA). Racks with a 0.5 stack are considered to be a strong stacking factor, whilst racks with a 0.5 stack are considered less than it would be reasonable to remove from the table.

\subsection{Convergent Validity}

Convergent validity is the degree to which two proportions of comparative development are reconciled in any case (Bligh, 2017). Collaborative legitimacy was assessed by examining the changes identified for each factor (Breevaart \& Zacher, 2019). If Fornell and Larcker (1981) are excluded, if the difference between the values is greater than 0.5 , uniform confidence is established and it is concluded that the loads are acceptable, but values less than 0.5 are considered smaller. convincing for research..

Table 1 shows the values of CR higher than 0.70. The AVE values are above 0.5 in all constructs apart from organisational deviance. Moreover, Cronbach's Alpha values are all above 0.8 making the values reliable (Butt et al., 2016).

Table 1. Construct validity and reliability

\begin{tabular}{|l|c|c|c|c|}
\hline & $\begin{array}{c}\text { Cronbach's } \\
\text { Alpha }\end{array}$ & rho_A & $\begin{array}{c}\text { Composite } \\
\text { Reliability }\end{array}$ & $\begin{array}{c}\text { Average Variance } \\
\text { Extracted (AVE) }\end{array}$ \\
\hline EL-U & 1.000 & 1.000 & 1.000 & 1.000 \\
\hline Ethical Leadership (EL) & $\mathbf{0 . 9 5 8}$ & $\mathbf{0 . 9 5 8}$ & $\mathbf{0 . 9 6 4}$ & $\mathbf{0 . 7 2 7}$ \\
\hline LXM & $\mathbf{0 . 7 1 1}$ & $\mathbf{0 . 7 1 7}$ & $\mathbf{0 . 8 7 3}$ & $\mathbf{0 . 7 7 5}$ \\
\hline Organisational Deviance (OD) & $\mathbf{0 . 8 9 6}$ & $\mathbf{0 . 9 1 2}$ & $\mathbf{0 . 9 1 4}$ & $\mathbf{0 . 4 9 4}$ \\
\hline Psychological attachment (PA) & $\mathbf{0 . 8 6 2}$ & $\mathbf{0 . 8 6 7}$ & $\mathbf{0 . 9 0 1}$ & $\mathbf{0 . 6 4 6}$ \\
\hline Utilitarianism (U) & $\mathbf{0 . 9 1 2}$ & $\mathbf{0 . 9 2 5}$ & $\mathbf{0 . 9 2 7}$ & $\mathbf{0 . 5 1 9}$ \\
\hline distributive justice (DJ) & 1.000 & 1.000 & 1.000 & 1.000 \\
\hline psychological safety (PS) & 1.000 & 1.000 & 1.000 & 1.000 \\
\hline
\end{tabular}




\subsection{Discriminant Validity}

Discriminate validity can be characterised as any single development that changes from model to model (Babič, 2014). Split legitimacy results are good if the developers have an AVE stack greater than 0.5 , which means that the base half of the difference was built. Segregated legitimacy is established if the distorted components significantly exceed these distorted qualities on equal lines and segments. Discriminant validity tests are performed to determine if unrelated thoughts or judgments are true or inappropriate. A powerful assessment of discriminant authenticity shows that prior information about thinking is not particularly relevant for various tests that are supposed to measure theoretically different thoughts. Table 2 shows adequate discriminant legitimacy. The quality of the solid ones (AVE square base) is higher, which makes them adequate. Table 2 demonstrates acceptable discriminant validity. The values in bold (square root of AVE) are higher which makes them acceptable.

Table 2. Fornell-Larcker Criterion

\begin{tabular}{|c|c|c|c|c|c|c|c|c|}
\hline & EL-U & $\begin{array}{l}\text { Ethical } \\
\text { Leadership } \\
\text { (EL) }\end{array}$ & $\begin{array}{l}\mathbf{L X} \\
\mathbf{M}\end{array}$ & $\begin{array}{l}\text { Organisational } \\
\text { Deviance (OD) }\end{array}$ & $\begin{array}{l}\text { Psychological } \\
\text { attachment } \\
\text { (PA) }\end{array}$ & $\begin{array}{l}\text { Utilitarian } \\
\operatorname{ism}(\mathbf{U})\end{array}$ & $\begin{array}{l}\text { distributive } \\
\text { justice (DJ) }\end{array}$ & $\begin{array}{l}\text { psychologica } \\
\text { I safety (PS) }\end{array}$ \\
\hline EL-U & 1.000 & & & & & & & \\
\hline $\begin{array}{l}\text { Ethical } \\
\text { Leadership } \\
\text { (EL) }\end{array}$ & 0.007 & 0.852 & & & & & & \\
\hline LXM & -0.085 & 0.732 & 0.881 & & & & & \\
\hline $\begin{array}{l}\text { Organisational } \\
\text { Deviance (OD) }\end{array}$ & -0.429 & 0.247 & 0.142 & 0.703 & & & & \\
\hline $\begin{array}{l}\text { Psychological } \\
\text { attachment } \\
\text { (PA) }\end{array}$ & -0.135 & 0.735 & 0.786 & 0.147 & 0.804 & & & \\
\hline $\begin{array}{l}\text { Utilitarianism } \\
\text { (U) }\end{array}$ & -0.173 & 0.612 & 0.611 & -0.020 & 0.652 & 0.720 & & \\
\hline $\begin{array}{l}\text { distributive } \\
\text { justice (DJ) }\end{array}$ & -0.157 & 0.479 & 0.583 & 0.244 & 0.569 & 0.380 & 1.000 & \\
\hline $\begin{array}{l}\text { psychological } \\
\text { safety (PS) }\end{array}$ & -0.146 & 0.659 & 0.676 & 0.145 & 0.663 & 0.579 & 0.422 & 1.000 \\
\hline
\end{tabular}

\subsubsection{Coefficient of Determination}

Table 3 shows that the $\mathrm{R}^{2}$ value is 0.536 for LMX. This indicates that 53.6 LMX is influenced by ethical leadership. Also, distributive justice is least influenced by ethical leadership with a value of 0.230 . 
Table 3. Coefficient of determination (R-value)

\begin{tabular}{|l|l|l|}
\hline & R Square & R Square Adjusted \\
\hline LMX & 0.536 & 0.534 \\
\hline Organisational Deviance (OD) & 0.365 & 0.346 \\
\hline Psychological attachment (PA) & 0.541 & 0.539 \\
\hline Utilitarianism (U) & 0.375 & 0.373 \\
\hline distributive justice (DJ) & 0.230 & 0.227 \\
\hline psychological safety (PS) & 0.435 & 0.432 \\
\hline
\end{tabular}

\subsection{Model Fit Measures}

The fitness of the model in SEM-PLS is characterised by different estimates, for example, the normalised root mean square residual (SRMR), and a particular model corresponds, for example, d_ULS and d_G, Normed Fit Index (NFI) and $\chi 2$ (Chi-square). Model fit measures involving deliberate evaluation of both impregnated models and the evaluated model are accounted for in the table above. An immersed model evaluates the relationship between everything that adds up. The evaluated model, again, takes into account the design of the model and depends on the absolute impact.

Table 4. Model fit summary

\begin{tabular}{|l|l|l|}
\hline & Saturated Model & Estimated Model \\
\hline SRMR & 0.069 & 0.086 \\
\hline d_ULS & 4.332 & 6.615 \\
\hline d_G & 1.202 & 1.384 \\
\hline Chi-Square & 1585.570 & 1791.988 \\
\hline NFI & 0.796 & 0.769 \\
\hline
\end{tabular}

\subsubsection{The Structural Model (Inner Model) and Hypotheses Testing}

The structural model helps to understand and study the complex relationships of factors, Aryati et al., (2018). The primary model was further tested and worked on SmartPLS 3.2.3. The base model was loaded. An image of the result after starting the test is shown under the link along with the translation of the results.

In PLS-SEM, bootstrapping is one of the key steps that provides information on the consistency of the factor estimate. Subtests are performed wherever the main model resides, including replacement, in this cycle. Bootstrapping provides data on the stability of the coefficient sensor. In this interaction, countless sub-examples are taken from the first substitution example Alpkan et al. (2020). After executing the bootstrap schedule, Smart PLS displays the t-values for the initial model estimates obtained using the bootstrap methodology. The significance of bias factors for the entire theory is presented in the attached table. The 


\section{Macrothink}

Global Journal of Educational Studies

ISSN 2377-3936 2021, Vol. 7, No. 2

T-score is more significant than 1.96 ( $\mathrm{p}<0.005)$, indicating that the relationship is critical at the 95\% confidence level $(\alpha=0.05)$. Methods for determining whether there is a strong link between evaluation and inefficiency. The path diagram showed in figure 1 .

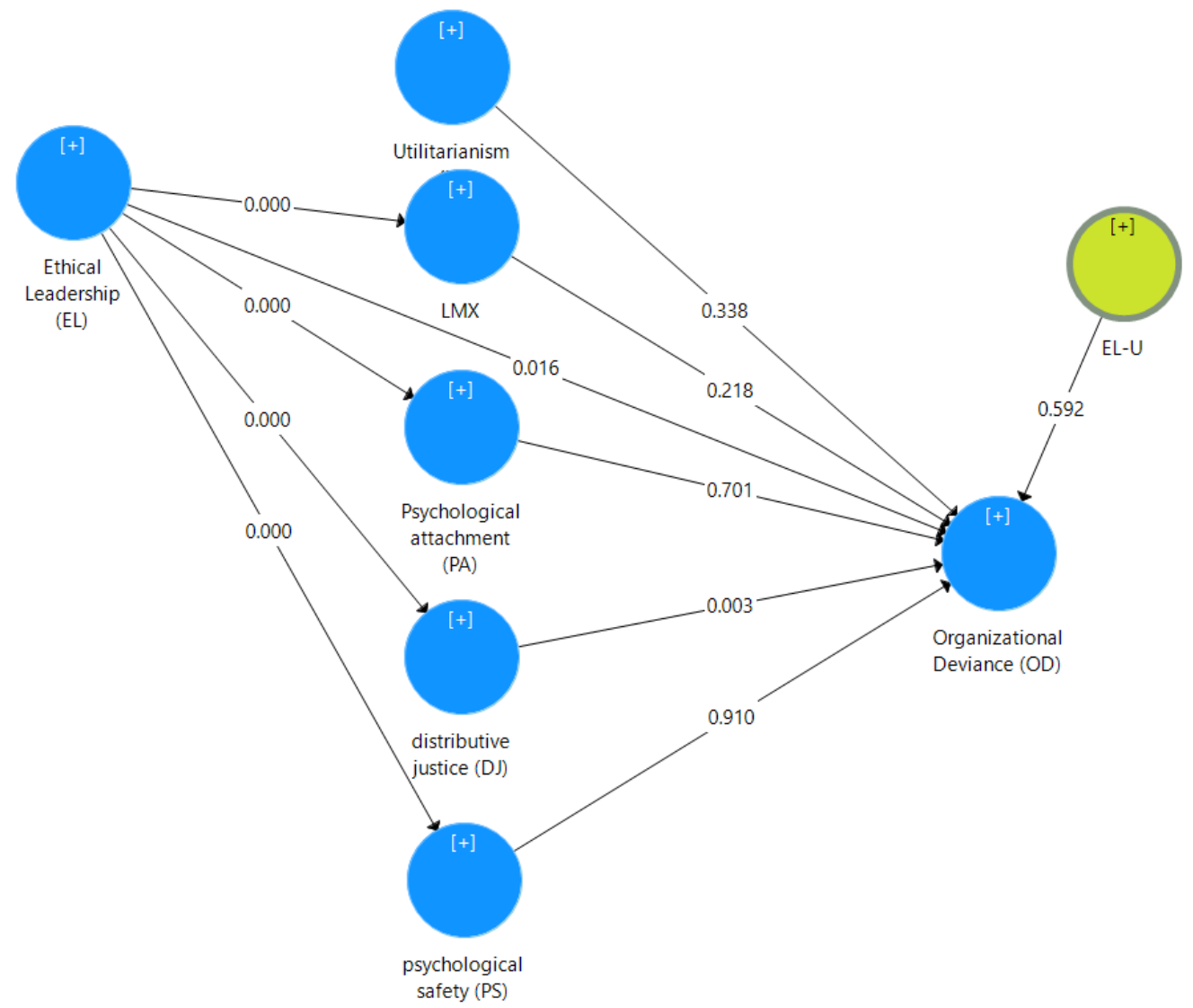

Figure 1. Path diagram of Ethical leadership

Table 7. Hypothesis Testing

\begin{tabular}{|l|l|l|l|}
\hline & $\begin{array}{l}\text { Original } \\
\text { Sample }(\mathbf{O})\end{array}$ & $\begin{array}{l}\text { T Statistics } \\
(\mid \mathrm{O} / \mathrm{STDEV})\end{array}$ & P Values \\
\hline EL-U -> Organisational Deviance (OD) & -0.483 & 7.905 & $\mathbf{0 . 0 0 0}$ \\
\hline Ethical Leadership (EL) -> LMX & 0.732 & 23.761 & $\mathbf{0 . 0 0 0}$ \\
\hline Ethical Leadership (EL) -> Organisational Deviance (OD) & 0.538 & 4.355 & $\mathbf{0 . 0 0 0}$ \\
\hline Ethical Leadership (EL) -> Psychological attachment (PA) & 0.735 & 22.096 & $\mathbf{0 . 0 0 0}$ \\
\hline Ethical Leadership (EL) -> Utilitarianism (U) & 0.612 & 11.801 & $\mathbf{0 . 0 0 0}$ \\
\hline Ethical Leadership (EL) -> distributive justice (DJ) & 0.479 & 9.370 & $\mathbf{0 . 0 0 0}$ \\
\hline Ethical Leadership (EL) -> psychological safety (PS) & 0.659 & 15.901 & $\mathbf{0 . 0 0 0}$ \\
\hline LMX -> Organisational Deviance (OD) & -0.067 & 0.605 & $\mathbf{0 . 5 4 6}$ \\
\hline Psychological attachment (PA) -> Organisational Deviance (OD) & -0.084 & 0.813 & $\mathbf{0 . 4 1 7}$ \\
\hline Utilitarianism (U) -> Organisational Deviance (OD) & -0.383 & 4.040 & $\mathbf{0 . 0 0 0}$ \\
\hline distributive justice (DJ) -> Organisational Deviance (OD) & 0.151 & 2.354 & $\mathbf{0 . 0 1 9}$ \\
\hline psychological safety (PS) -> Organisational Deviance (OD) & -0.022 & 0.263 & $\mathbf{0 . 7 9 2}$ \\
\hline
\end{tabular}




\section{MInstitute Macrothink $_{\text {Int }}$}

Global Journal of Educational Studies

ISSN 2377-3936

Table 7 shows that $\mathrm{H} 2 \mathrm{a}, \mathrm{H} 2 \mathrm{~b}$ and $\mathrm{H} 2 \mathrm{c}$ have been rejected whilst all the other hypotheses have been accepted. This is because the p values of $\mathrm{H} 2 \mathrm{a}, \mathrm{H} 2 \mathrm{~b}$ and $\mathrm{H} 2 \mathrm{c}$ are above 0.005 which is not acceptable. This further implies that there is no significant relationship between LMX, psychological safety, psychological attachment, and organisational deviance.

\subsection{Mediation Analysis}

According to the recommendation of Williams, Vandenberg, and Edwards (2009) the intervention or mediation impact can be culminated when the product of the way between Exogenous variable and the mediator (named as path a) and the way between mediator and endogenous variable (named as path b) are significant statistically. (Base ppr). Thus, mediation analysis is used to evaluate the cause and effect relationship between an independent and dependent variable through the involvement of third illustrative mediator variable (Hair et al., 2016). The approach of bootstrapping is appropriate for mediation investigation in the light of fact that it makes no supposition about the sampling division of statistics and can be applied to little sample sizes (Hair et al., 2016). In PLS- SEM ,to draw the mediation analysis the initial step is to evaluate the direct or immediate impact of independent variables on the endogenous variable, which ought to be significant if mediator is not involved (Zhao, Lynch, \& Chen, 2010).

Below is the table of Specific Indirect Effects showing the mediating effects result.

\subsubsection{Mediation Analysis}

Strong mediation effect is found between ethical leadership, utilitarianism and organisational deviance as $\mathrm{P}$ values are less than 0.05. Moreover, table 6 also shows a strong mediation effect between ethical leadership, distributive justice and organisational deviance.

Table 6. Mediation analysis

\begin{tabular}{|l|l|l|l|}
\hline & $\begin{array}{l}\text { Original } \\
\text { Sample (O) }\end{array}$ & $\begin{array}{l}\text { T } \\
(|\mathrm{O} / \mathrm{STDEV}|\end{array}$ & P Values \\
\hline Ethical Leadership (EL) -> LXM -> Organisational Deviance (OD) & -0.049 & 0.601 & $\mathbf{0 . 5 4 8}$ \\
\hline $\begin{array}{l}\text { Ethical Leadership (EL) -> Psychological attachment (PA) -> } \\
\text { Organisational Deviance (OD) }\end{array}$ & -0.062 & 0.807 & $\mathbf{0 . 4 2 0}$ \\
\hline $\begin{array}{l}\text { Ethical Leadership (EL) -> Utilitarianism (U) -> Organisational } \\
\text { Deviance (OD) }\end{array}$ & -0.235 & 3.791 & $\mathbf{0 . 0 0 0}$ \\
\hline $\begin{array}{l}\text { Ethical Leadership (EL) -> distributive justice (DJ) -> } \\
\text { Organisational Deviance (OD) }\end{array}$ & 0.072 & 2.237 & $\mathbf{0 . 0 2 6}$ \\
\hline $\begin{array}{l}\text { Ethical Leadership (EL) -> psychological safety (PS) -> } \\
\text { Organisational Deviance (OD) }\end{array}$ & -0.015 & 0.261 & $\mathbf{0 . 7 9 4}$ \\
\hline
\end{tabular}


2.11.2 Moderation Analysis

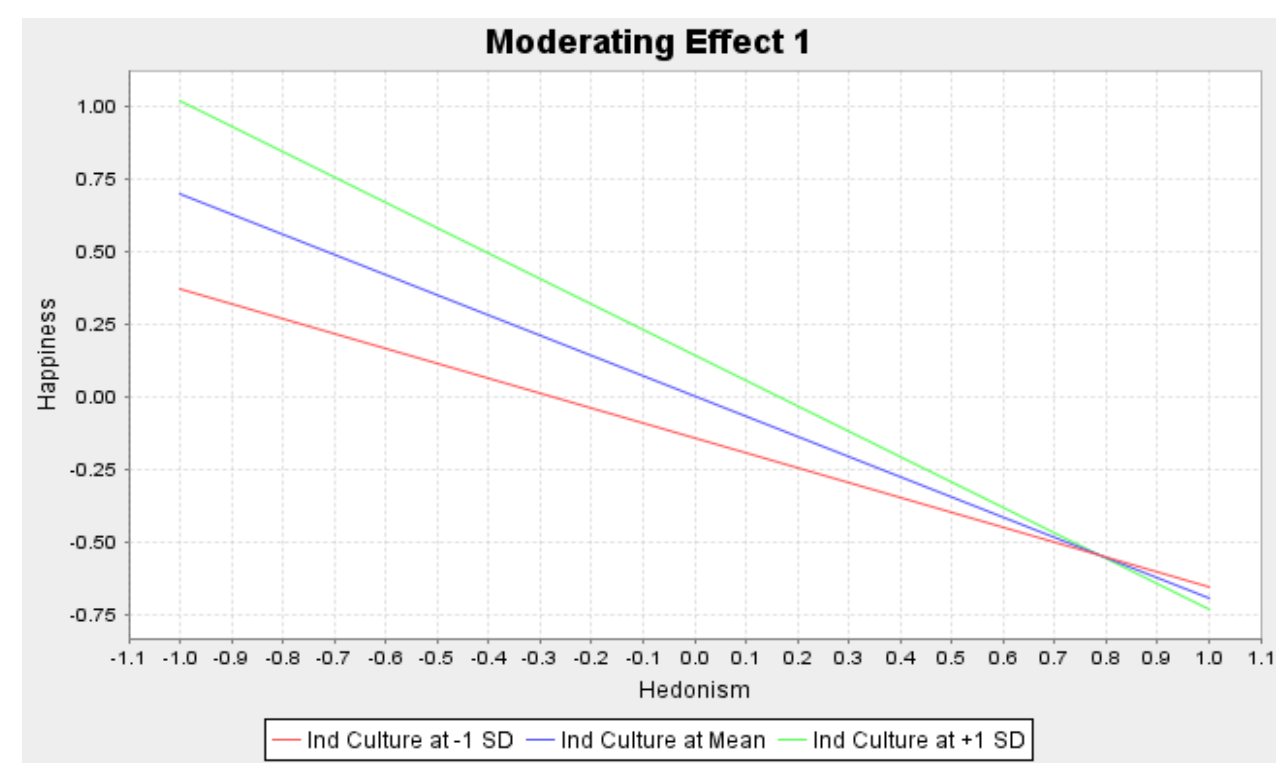

\section{Discussion}

\begin{tabular}{|l|l|l|l|}
\hline \multicolumn{1}{|c|}{ Hypothesis } & Est. & P -values & Decision \\
\hline $\begin{array}{l}\text { Ethical Leadership behaviour has a positive influence on } \\
\text { LMX }\end{array}$ & & & \\
\hline $\begin{array}{l}\text { Ethical Leadership and distributive justice are positively } \\
\text { related to each other }\end{array}$ & & & \\
\hline
\end{tabular}

As per the suggestion of literature, ethical leadership impacts organisational deviance and some mediating factors are also influenced by ethical leadership, this article tested hypotheses. Concerning the findings of the study, it can now be concluded that ethical leadership and organisational deviance have a strong negative relationship. Workplace deviance can be eliminated through the introduction of honest and trustworthy leaders that show care, concern and support their subordinates. Trust mediates the reduction in organisational deviance as employees tend to perceive their leaders to their perceived ethical values.

Ethical leadership has a positive relationship with all the factors - psychological safety, psychological attachment, distributive justice, Leader-Member Exchange (LMX). When leaders act ethically, employees begin to trust them, and this trust mediates the feeling of safety and attachment toward the workplace. Moreover Alpkan et al. (2020), fair and ethical leaders encourage communication and interaction between employees that gives employees a feeling of belongingness.

Psychological safety and attachment, and leader-member exchange (LMX) have shown no significant relationship with organisational deviance according to the results of the study. This further concludes that employees may still act in deviance toward organisations even if they are 
provided with safe working environments and have good communication with their leaders. On the other hand, distributive justice, when high eliminates the possibility of organisational deviance as employees are satisfied with the way rewards and opportunities to have been distributed amongst each other.

Some hypotheses were accepted whilst some rejected and the details are given below.

\section{H1a: Ethical Leadership behaviour has a positive influence on LMX}

The research findings correlate with previous theoretical research and the hypothesis is accepted. The results of this study are consistent with that of the study conducted by Haar et al., (2019) that says that employee's value ethical leadership and it is the support that improves leader-member exchange. Through this study the role of ethical leadership in employee advice seeking by inspecting how and when ethical leadership may exert a positive influence on advice seeking. According to the findings, ethical leadership and LMX are positively related in Pakistan in the banking sector like that of ŠejlaBabič (2014) in the telecommunication sector.

Thus, Al Halbusi et al. (2017) suggested the influence on the LMX of factors of race, the level of education of participants, initial productivity of work, off-duty behaviour and used in developing a model for achieving attributive theory, social exchange and influence; drew attention to the active influence of followers on the leader (including newcomers). A.S. Kozlowski and M. Douherty showed a connection between a high LMX and a positive and similar to leadership perception of the psychological climate of the organisation in subordinates. In response to criticism of patriarchy, the $L M X$ theory was expanded to include gender, and the emphasis shifted to the study of gender differences in leaders Al-Hakim et al., (2020) and the connection with integration. In general, despite criticism (in particular, about the narrowness of the approach, lack of attention to the most important situational variables), the $L M X$ theory remains one of the most popular, and not only in the Pakistan, but also in other countries

\section{H1b: Ethical Leadership has a positive relationship with psychological safety.}

The results of the study show the above hypothesis has been accepted. Employees feel safe when working with an ethical leader. Employees feel relax to working in safe environment and have mentally relaxation regarding job and its responsibilities. At the same time it helps employee to be honest and responsible for the firm. The findings of this study are in line with the study of Newman et al. (2017) implying that support and care from leaders make employees feel safe in the work environment.

In addition, when the leaders of the organisation demonstrate respect, understanding, honesty in relations with stakeholders, a long-term approach to results in daily activities and strategic choice in favour of not only current financial benefits, but also concern for the development of future generations and society as a whole, the organisation gains a high ethical reputation. The perception of an organisation as ethical and virtuous will contribute to the growth of trust in it and, as a result, the formation of consumer loyalty. The author emphasizes that the psychological processes through which consumer trust and loyalty are formed take a significant amount of time and will affect the results of the organisation in the long term, but 
not in the short term.

The ethics of Western leadership is formed on the basis of value orientations in the spirit of consequentialism, pragmatism and perfectionism. The main social guidelines of a leader include the desire for material well-being, career growth, social status, etc. In addition, leadership in Western culture is seen as an independent value of society as a whole, since it includes the concept of self-improvement - one of the key points in the psychology of Western people.

\section{H1c: There is a positive relationship between ethical leadership and psychological attachment}

It has been represented by the findings of the study that ethical leadership and psychological attachment relate with each other positively, in that ethical leadership practices bring employees to commit to organisations and work for the best interests of the organisations instead of their own. The workers send positive impact to the firm, the employee take interest in multiple activities and try to give the best input as much as they can. Past studies such as that of Dust et al. (2018) have findings in correspondence to this article which further implies that prior researches also support this hypothesis.

\section{H1d: Ethical Leadership and distributive justice are positively related to each other}

The hypothesis is accepted concerning the results of the study. The findings suggest that there is a significant positive relationship between ethical leadership and distributive justice. Al Habusi et al. (2017) stated that when distributive justice is high, employees feel motivated to work as there is not only the equal distribution of rewards and opportunities but also concern and care from leaders. the demand for distributive justice formulated in the third principle is undergoing a significant shift. In the Belmont report, this principle was formulated bearing in mind the risks of exploitation by researchers of vulnerable or discredited subjects ( experimental in corpore vili) (Chamayou, 2008). In fact, by adopting a participatory approach and provided that they are honestly conducted, RPCs do not seem to present a risk of distributive injustice: the burden of research and its expected benefits are attached, in principle, to the same people. In addition, the PRC's bias in favor of autonomy and empowerment of participants positions this kind of research as a means to correct pre-existing injustices, by addressing inequalities of condition. Some authors thus tend to reinterpret the principle, stated in the Belmont report as "distributive justice", in the sense of "relational justice" (King, Henderson and Stein, 1999).

\section{H1e: Ethical leadership and organisational deviance have a negative significant relationship}

There is a negative relationship between organisational deviance and ethical leadership thus accepting the above hypothesis. Similarly, past studies conducted by Christian and Ellis (2014) have supported the fact that strong ethical leadership behaviour stimulates a reduction in deviant workplace behaviour.

\section{H2a: LMX is negatively related to organisational deviance}


The findings revealed that LMX and organisational deviance have no significant relationship with one another. Thus, the hypothesis has been rejected. Whilst the findings of Hu et al. (2018) have supported this hypothesis, which is in contrast with the survey findings identified in Pakistan. The difference in the results can possibly be due to cultural differences in the management of organisations as well as the preferences of employees in different countries.

H2b: Psychological safety and organisational deviance are negatively related to each other.

The above hypothesis is rejected as the findings of this study suggest that there is no significant negative relationship between psychological safety and organisational deviance. The study of Erkutlu and Chafra (2019) contradicts the findings of this study. The change in results might be due to cultural gaps, norms and values of society. The adoption of transgressive, deviant behaviour, outside the norms and rules established by their practice, their organisation or their manager and which have a strong chance of being sanctioned. Nevertheless, these individuals who can be described as "positive deviants" all have the will to bring a benefit to their organisation or to its members.

\section{H2c: There is a negative significant relationship between psychological attachment and organisational deviance}

The above hypothesis is rejected as the findings of the study suggest that there is no significant negative relationship between psychological attachment and organisational deviance. Hackett et al. (2018) suggested that even though employees are psychologically attached to their work, they can act in deviance in the workplace. At the same time, researchers are seeing an increase in the prevalence of destructive behaviour within companies, also known as negative deviant behaviour. For example, almost $95 \%$ of employees report having experienced negative deviant behaviour within their organisations.

\section{H2d: Utilitarianism is negatively related to organisational deviance}

The findings of the study suggest that utilitarianism is negatively related to organisational deviance thus accepting the above hypothesis. Monrouxe and Rees (2017) have supported the hypothesis as well in their study implying that high utilitarianism practices will bring about a reduction in deviant behaviour amongst employees in an organisation.

\section{H2e: Distributive justice is negatively related to organisational deviance}

The above hypothesis has been accepted in line with the findings of the research. Significantly, distributive justice and organisational deviance are negatively related implying that with high levels of distributive justice employees engage less in deviant behaviour. The findings of this study are in correspondence with the findings of Dar (2017). Alpkan et al. (2020) investigated the relationship of distributive justice and organisational deviance in Turkey in the banking sector and the findings of the study are in line with this study conducted in Pakistan.

H3: Ethical leadership - utilitarianism and organisational deviance are positively related to each other 
The findings of the study suggest that there is a negative significant relationship between ethical leadership - utilitarianism and organisational deviance. Gerpott et al. (2019) noted that utilitarian ethical leadership helps avoid workplace deviance behaviour. The study of Gill et al. (2016) has similar findings to that of this study further supporting the hypothesis of the study.

\section{Conclusion}

For organisations to improve leadership, training programs need to be introduced to encourage leaders to work in ethical manners. Furthermore, role reversal can be done for a specific period to make the leaders understand what employees feel when they are controlled by their leaders. This will help them empathise with the employees and reduce any immoral behaviour that may result in negative relations with the employees. Furthermore, organisations can introduce incentives, rewards and promotional strategies to induce the reduction of organisational deviance.

Employees need to enrol in behaviours that present them in good light. Organisations should increase employee involvement in CSR activities to develop in them positive behavioural change. This will help bring progress for the organisation as well as the employee on an individual level. Engaging in CSR activities will further attract more customers toward the organisations. Thus, the productivity of organisations will increase. Furthermore, employees should be enrolled into training programs that will help them learn the skills required to work in environments that might involve possible conflicts of interest.

\subsection{Practical and Theoretical Implications}

The model of this study is quite novel in the context of Pakistan. Past researches have not considered the mediating factors. Thus, very little attention has been given to these in previous studies. This article has filled this gap in literature. Through this study, managers will be able to understand the different aspects of the organisational environment that are possibly new to the Pakistani organisational culture Abdillah et al. (2020). Concepts such as distributive justice and LMX will be better put to the forefront enabling managers to understand the shortcoming of their companies and create strategies accordingly. Moreover, leaders will learn the importance of trust between leaders and employees as it is this relationship that fosters mutual decision-making and respect.

\subsection{Research Limitations}

The article came across a few limitations that may have influenced the degree of accuracy. This study solely focused on the banking sector which has a high strength of rules and regulations. The main banks referred to were Habib Bank, Faysal Bank, Meezan Bank, Sindh Bank, Bank Al Habib and Soneri Bank. This may have impacted the psychological factor results in the study. Furthermore, other situational factors such as procedural justice and Corporate Social Responsibility (CSR) were not included in the study limiting the coverage of the information. The sample size of the study was also small. Thus, leading to limited responses as some participants failed to provide complete information. 


\subsection{Future Work}

For future research, researchers can also add situational factors like procedural justice, CSR, employee empowerment and emotional attachment to assess the effect of ethical leadership on them and how these factors help in mediating a reduction in organisational deviance. Moreover, larger sample size can be used in later studies to avoid any anomalies in the result. Other researchers may also choose to conduct the same study in a different sector such as the energy sector in Pakistan. This is because the energy sector faces huge challenges regarding leadership due to the high levels of corruption in the country.

\section{References}

Abdillah, M. R., Wu, W., \& Anita, R. (2020). Can altruistic leadership prevent knowledge-hiding behaviour? Testing dual mediation mechanisms. Knowledge Management Research \& Practice, 1-15.

Al Halbusi, H., Tehseen, S., \& Ramayah, T. C. (2017). The impact of organisational justice on the ethical leadership under the moderating influence of perceived support: A conceptual study. Malaysian Journal of Business and Economics (MJBE).

Al-Hakim, M. L., \& Soetjipto, B. W. (2020). The Effects of Leader-Member Exchange and Fun at Work on Work Engagement and Deviant Workplace Behaviour in Indonesian Telecommunication Company. KnE Social Sciences, 266-279.

Alpkan, L., Karabay, M., Şener, İ., Elçi, M., \& Yıldız, B. (2020). The mediating role of trust in the leader in the relations of ethical leadership and distributive justice on internal whistleblowing: A study on the Turkish banking sector. Kybernetes.

Aryati, A. S., Sudiro, A., Hadiwidjaja, D., \& Noermijati, N. (2018). The influence of ethical leadership to deviant workplace behaviour mediated by ethical climate and organisational commitment. International Journal of Law and Management.

Babič, Š. (2014). Ethical Leadership and Leader-Member Exchange (LMX) Theory. CRIS Bulletin of the Centre for Research and Interdisciplinary Study (pp. 62-64). Retrieved from https://www.researchgate.net/publication/275994451_Ethical_Leadership_and_Leader_Mem ber_Exchange_LMX_Theory

Bligh, M. C. (2017). Leadership and trust. Leadership today (pp. 21-42). Springer, Cham.

Breevaart, K., \& Zacher, H. (2019). Main and interactive effects of weekly transformational and laissez-faire leadership on followers' trust in the leader and leader effectiveness. Journal of Occupational and Organisational Psychology, 92(2), 384-409.

Butt, A., Butt, A., \& Ayaz, M. (2016). Impact of ethical leadership on organisational performance and mediating role of corporate social responsibility: Evidence from the banking sector of Pakistan. International Journal of Management Sciences and Business Research, $5(6)$.

Christian, J. S., \& Ellis, A. P. (2014). The crucial role of turnover intentions in transforming 
moral disengagement into deviant behaviour at work. Journal of Business Ethics, 119(2), 193-208.

Chughtai, A. A. (2016). Servant leadership and follower outcomes: Mediating effects of organisational identification and psychological safety. The Journal of Psychology, 150(7), 866-880.

Cropanzano, R., Anthony, E. L., Daniels, S. R., \& Hall, A. V. (2017). Social exchange theory: A critical review with theoretical remedies. Academy of Management Annals, 11(1), 479-516.

Dar, N. (2017). The impact of distributive (in) justice on deviance at the workplace in public sector organisations of Pakistan with the mediation of perceived organisational support. Arabian J Bus Manag Review, 7, 309.

Decoster, S., Stouten, J., \& Tripp, T. M. (2019). When employees retaliate against self-serving leaders: The influence of the ethical climate. Journal of Business Ethics, 1-19.

Dust, S. B., Resick, C. J., Margolis, J. A., Mawritz, M. B., \& Greenbaum, R. L. (2018). Ethical leadership and employee success: Examining the roles of psychological empowerment and emotional exhaustion. The Leadership Quarterly, 29(5), 570-583.

Erkutlu, H., \& Chafra, J. (2015). The mediating roles of psychological safety and employee voice on the relationship between conflict management styles and organisational identification. American Journal of Business.

Erkutlu, H., \& Chafra, J. (2019). Leader psychopathy and organisational deviance: the mediating role of psychological safety and the moderating role of moral disengagement. International Journal of Workplace Health Management, 12(4), 197-213.

Forthmann, B., Jendryczko, D., Scharfen, J., Kleinkorres, R., Benedek, M., \& Holling, H. (2019). Creative ideation, broad retrieval ability, and processing speed: A confirmatory study of nested cognitive abilities. Intelligence, 75, 59-72.

Frederiks, E., Spinks, A., Hobman, E., \& Dane, S. (2016). Pathways for primary data collection in EUDM. Australia: CSIRO.

Friedland, J., Emich, K., \& Cole, B. M. (2020). Uncovering the moral heuristics of altruism: A philosophical scale. PloS one, 15(3), e0229124.

Gerpott, F. H., Van Quaquebeke, N., Schlamp, S., \& Voelpel, S. C. (2019). An identity perspective on ethical leadership to explain organisational citisenship behaviour: The interplay of follower moral identity and leader group prototypicality. Journal of Business Ethics, 156(4), 1063-1078.

Gill, S. S., Haider, S., \& Noreen, S. (2016). Linking ethical leadership with organisational deviance and CSR: Empirical review. Asian Journal of Multidisciplinary Studies, 4(6), 23-28.

Gils, S., van, Quaquebeke, N. V., Knippenberg, D., \& Dijke, M. (2014). Ethical leadership and follower organisational deviance: The moderating role of follower moral attentiveness. The Leadership 
https://www.researchgate.net/publication/265788825_Ethical_leadership_and_follower_orga nisational_deviance_The_moderating_role_of_follower_moral_attentiveness

Haar, J., Roche, M., \& Brougham, D. (2019). Indigenous insights into ethical leadership: A study of Māori leaders. Journal of Business Ethics, 160(3), 621-640.

Hackett, R. D., Wang, A. C., Chen, Z., Cheng, B. S., \& Farh, J. L. (2018). Transformational Leadership and Organisational Citisenship Behaviour: A Moderated Mediation Model of Leader-Member-Exchange and Subordinates' Gender. Applied Psychology, 67(4), 617-644.

Hu, Y., Zhu, L., Zhou, M., Li, J., Maguire, P., Sun, H., \& Wang, D. (2018). Exploring the influence of ethical leadership on voice behaviour: how leader-member exchange, psychological safety and psychological empowerment influence employees' willingness to speak out. Frontiers in Psychology, 9, 1718.

Huhtala, M., \& Feldt, T. (2016). The path from ethical organisational culture to employee commitment: Mediating roles of value congruence and work engagement. Scandinavian Journal of Work and Organisational Psychology, 1 .

Jehanzeb, K., \& Mohanty, J. (2019). The mediating role of organisational commitment between organisational justice and organisational citisenship behaviour. Personnel Review.

Kim, M. S., \& Koo, D. W. (2017). Linking LMX, engagement, innovative behaviour, and job performance in hotel employees. International Journal of Contemporary Hospitality Management.

Lindebaum, D., Geddes, D., \& Gabriel, Y. (2017). Moral emotions and ethics in organisations: Introduction to the special issue. Journal of Business Ethics, 141(4), 645-656.

Luke, M. A., Carnelley, K. B., \& Sedikides, C. (2020). Attachments in the workplace: How attachment security in the workplace benefits the organisation. European Journal of Social Psychology, 50(5), 1046-1064.

Lysova, E. I., Allan, B. A., Dik, B. J., Duffy, R. D., \& Steger, M. F. (2019). Fostering meaningful work in organisations: A multi-level review and integration. Journal of Vocational Behaviour, 110, 374-389.

Mohammad, J., Quoquab, F., Idris, F., Al Jabari, M., \& Wishah, R. (2019). The mediating role of overall fairness perception: a structural equation modelling assessment. Employee Relations: The International Journal.

Monrouxe, L. V., \& Rees, C. E. (2017). Healthcare professionalism: Improving practice through reflections on workplace dilemmas. John Wiley \& Sons.

Mozumder, N. A. (2018). A multilevel trust-based model of ethical public leadership. Journal of Business Ethics, 153(1), 167-184.

Neves, P., \& Story, J. (2015). Ethical leadership and reputation: Combined indirect effects on organisational deviance. Journal of Business Ethics, 127(1), 165-176. 


\section{$\Lambda$ Macrothink}

Global Journal of Educational Studies

ISSN 2377-3936

2021, Vol. 7, No. 2

Newman, A., Donohue, R., \& Eva, N. (2017). Psychological safety: A systematic review of the literature. Human Resource Management Review, 27(3), 521-535.

Niemeyer, J. R. L., \& Cavazotte, F. D. S. C. N. (2016). Ethical leadership, leader-follower relationship and performance: A study in a telecommunications company. RAM. Revista de Administração Mackenzie, 17(2), 67-92.

Pang, A., Shin, W., Lew, Z., \& Walther, J. B. (2018). Building relationships through dialogic communication: organisations, stakeholders, and computer-mediated communication. Journal of Marketing Communications, 24(1), 68-82.

PircherVerdorfer, A., \& Peus, C. (2020). Leading by example: Testing a moderated mediation model of ethical leadership, value congruence, and followers' openness to ethical influence. Business Ethics: A European Review, 29(2), 314-332.

Qing, M., Asif, M., Hussain, A., \& Jameel, A. (2019). Exploring the impact of ethical leadership on job satisfaction and organisational commitment in public sector organisations: The mediating role of psychological empowerment. Review of Managerial Science, 1-28.

Quinlan, C., Babin, B., Carr, J., \& Griffin, M. (2019). Business research methods. South-Western Cengage.

Rani, N., \& Samuel, A. (2016). A study on generational differences in work values and person-organisation fit and its effect on turnover intention of Generation $\mathrm{Y}$ in India. Management Research Review.

Shareef, R. A., \& Atan, T. (2019). The influence of ethical leadership on academic employees' organisational citisenship behaviour and turnover intention. Management Decision.

Sharma, A., Agrawal, R., \& Khandelwal, U. (2019). Developing ethical leadership for business organisations. Leadership \& Organisation Development Journal.

Sreeprabha, R. (2018). Value-Driven Leadership during the Complexity of Change-A Review. Asian Journal of Research in Social Sciences and Humanities, 8(12), 6-13.

Steinmann, B., Klug, H. J., \& Maier, G. W. (2018). The path is the goal: how transformational leaders enhance followers' job attitudes and proactive behaviour. Frontiers in Psychology, 9, 2338.

Sujati, H., \& Akhyar, M. (2020). Testing the Construct Validity and Reliability of Curiosity Scale Using Confirmatory Factor Analysis. Journal of Educational and Social Research, 10(4), 229-229.

Taber, K. S. (2018). The use of Cronbach's alpha when developing and reporting research instruments in science education. Research in Science Education, 48(6), 1273-1296.

Valle, M., Kacmar, K. M., Zivnuska, S., \& Harting, T. (2019). Abusive supervision, leader-member exchange, and moral disengagement: A moderated mediation model of organisational deviance. The Journal of social psychology, 159(3), 299-312. 


\section{Macrothink}

Global Journal of Educational Studies

ISSN 2377-3936 2021, Vol. 7, No. 2

van Berkel, N., Tag, B., Goncalves, J., \& Hosio, S. (2020). Human-centred artificial intelligence: a contextual morality perspective. Behaviour \& Information Technology, 1-17.

Weiss, M., Kolbe, M., Grote, G., Spahn, D. R., \& Grande, B. (2018). We can do it! Inclusive leader language promotes voice behaviour in multi-professional teams. The Leadership Quarterly, 29(3), 389-402.

Xu, A. J., Loi, R., \& Ngo, H. Y. (2016). Ethical leadership behaviour and employee justice perceptions: The mediating role of trust in an organisation. Journal of Business Ethics, 134(3), 493-504.

Yuan, L., Vu, M. C., \& Nguyen, T. T. N. (2018). Ethical leadership, leader-member exchange and voice behaviour: Test of mediation and moderation processes. In Proceedings of the 2018 2nd International Conference on Management Engineering, Software Engineering and Service Sciences (pp. 33-42).

Zoghbi-Manrique-de-Lara, P., \& Viera-Armas, M. (2019). Does ethical leadership motivate followers to participate in delivering compassion? Journal of Business Ethics, 154(1), 195-210.

\section{Copyright Disclaimer}

Copyright for this article is retained by the author(s), with first publication rights granted to the journal.

This is an open-access article distributed under the terms and conditions of the Creative Commons Attribution license (http://creativecommons.org/licenses/by/3.0/). 